\section{Influence of Zirconia-Coated Bioactive Glass on Gingival Fibroblast Behavior}

Suelen Aline de Lima Barros $^{1}{ }^{-0}$, Diana Gabriela Soares ${ }^{2}$, , Maria Luísa

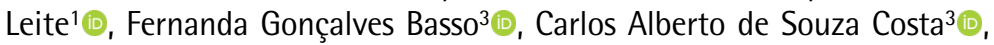
Gelson Luis Adabo ${ }^{1}$ (D)
'Department of Dental Materials and Prosthodontics, Araraquara School of Dentistry, UNESP -Universidade Estadual Paulista, Araraquara, SP, Brazil ${ }^{2}$ Department of Operative Dentistry, Endodontics and Dental Materials, USP - Universidade de São Paulo, Bauru, SP, Brazil ${ }^{3}$ Department of Physiology and Pathology, Araraquara School of Dentistry, UNESP Universidade Estadual Paulista, Araraquara, SP, Brazil

Correspondence: Gelson Luís Adabo, Rua Humaitá, 1680, 14801-903 Araraquara, SP, Brasil. Tel:+55-16 3301-64157. e-mail: adabo@foar.unesp.br

Key Words: surface-coated materials, bioglass, zirconia, fibroblasts, bioactivity.

\section{Introduction}

Zirconia abutments have been widely used in implant dentistry due to their superior aesthetic appearance compared with that of titanium, along with their biocompatibility with bone and gingival tissues, low bacterial adherence, suitable mechanical properties, and chemical stability (1). However, the success of dental implants also depends upon the establishment and maintenance of a stable attachment and efficient seal between the abutment surface and surrounding soft tissue at the abutment surface and/or transmucosal portion of the implants (2). This connective tissue attachment prevents apical migration of epithelium (3), acting as a biological barrier against adhesion and penetration of bacteria along the alveolar bone, preventing, in turn, bone loss at this critical region (4).

The morphological, physical, and chemical characteristics of abutment materials' surfaces play a significant role in epithelial, fibroblast, and osteoblast behavior (5). Several surface treatments of abutments - such as polishing, sandblasting, acid etching, and laser irradiation - have been proposed to improve the biological response of the host tissue, with the goal of altering the microtopography and free energy surface $(2,4)$. An interesting histopathological study in human subjects demonstrated that an abutment surface with increased surface free energy led to improvement of the soft-tissue seal, characterized by the deposition of dense collagen fibers mediated by high numbers of adherent fibroblasts (5). Researchers have also demonstrated that a micrometer-scale rough surface is prone to fibroblast adhesion and soft-tissue seal, avoiding unwanted adhesion and apical migration of epithelial cells (4). Bioactive coating of implant or abutment surfaces has received attention due to its influence on local fibroblast responses, reducing wound-healing time and improving neo-tissue genesis. Zirconia surface coatings made of bioactive glasses (BG) have been proposed to increase the bioactivity with osteoblasts, aiming to reduce the osteointegration period and to slow the marginal bone loss following implantation (6). However, there is a dearth of studies aimed at the development of a BG coating to modulate fibroblast behavior on abutment surfaces. It was recently demonstrated that Biosilicate ${ }^{\circledR}$ (Vitrovita, São Carlos, SP, Brazil), which has the well-described potential to biostimulate osteoblasts to deposit mineralized matrix in vitro and in vivo $(6,7)$, may also induce gingival fibroblasts (GFs) to proliferate significantly over time (8). Therefore, in this study we proposed to use Biosilicate ${ }^{\circledR}$ to develop a bioactive coating on zirconia surfaces. The chemical and physical characteristics of this new surface as well as its role in a fibroblast cell lineage proliferation, spread, migration, and collagen expression were assessed. The null hypothesis 
was that BS covering would have no effect on fibroblast behavior on zirconia surfaces.

\section{Material and Methods}

\section{Obtaining Zirconia Discs}

Green-state zirconia discs (Vita InCeram YZ, VITA Zahnfabrik, Bad Säckingen, BW, Germany; diameter, 9 mm; thickness, $2 \mathrm{~mm}$ ) were obtained and then subjected to wet-grinding followed by polishing with 2000-grit abrasive paper (3M, Sumaré, SP, Brazil). The specimens were cleaned in an ultrasonic bath (Cleaner 1440D, ODONTOBRAS, Ribeirão Preto, SP, Brazil) for three cycles of 15 min each, then dried at $100^{\circ} \mathrm{C}$ for $24 \mathrm{~h}$ (Orion 515, FANEM, Guarulhos, $\mathrm{SP}$, Brazil). The discs were then sintered in a Sirona inFire HTC speed oven (Sirona, Bensheim, HE, Germany) following the manufacturer's instructions, yielding specimens $1.6 \mathrm{~mm}$ thick and $7.2 \mathrm{~mm}$ in diameter.

\section{Biosilicate ${ }^{\circledR}$ Covering}

First, the amount of Biosilicate ${ }^{\circledR}$ (BS; 30-60 $\mu \mathrm{m}$ particle size; kindly donated by LaMaV/UFSCar) capable of covering 100\% of a zirconia surface was established in pilot studies (data not shown). Based on that parameter, \& a $10 \%$ less-concentrated BS solution was used to prepare the experimental BS-covered zirconia surface. This BS concentration was based on the recommendations of Kido et al. (10), who demonstrated that $10 \%$ BS significantly $\sim$ increased $L 929$ fibroblast cell proliferation over time. Therefore, a suspension of $6 \mathrm{mg} / \mathrm{mL}$ of Biosilicate ${ }^{\circledR}$ powder in distilled water/isopropyl alcohol (1:1) was prepared and applied $(20 \mu \mathrm{L})$ to zirconia discs, followed by a thermal treatment at $1100^{\circ} \mathrm{C}$ for $20 \mathrm{~min}$ (temperature rate increase set at $15^{\circ} \mathrm{C} / \mathrm{min}$; F3000, EDG, São Carlos, SP, Brazil).

\section{Surface Topography and Composition}

Scanning electron microscopy (SEM; JMS-6610V Scanning Microscope, Tokyo, Japan) coupled with energydispersive X-ray spectroscopy (EDX) was used to observe the morphology and chemical composition of samples. Immediately after the thermal treatment, zirconia ( $\mathrm{Zr}$ ) and BS-covered zirconia $(\mathrm{Zr}+\mathrm{BS})$ discs were placed on metallic stubs, and material surfaces were covered with gold. SEM analysis was performed at $12 \mathrm{kV}$ voltage, obtaining representative images at $140 \mathrm{x}$ and $4500 \mathrm{x}$ magnification. EDX evaluation was performed on plain zirconia surfaces and on the particles found covering the samples in the $\mathrm{Zr}+\mathrm{BS}$ group.

\section{Surface Roughness}

The disc surfaces were also evaluated by confocal microscopy (LEXT 3D Measuring Laser Microscope OLS4100, Olympus, Waltham, MA, USA), with $\pm 2 \%$ accuracy, 0.8 $\mathrm{nm}$ scale resolution, $10 \mathrm{~nm}$ resolution movement, 50x repeatability, $n-1=0.012 \mu \mathrm{m}$, and $0.2+\mathrm{L} / 100 \mu \mathrm{m}$ precision. Peak-to-valley surface roughness ( $\mathrm{Ra}$ ) measurements were obtained through the virtual images obtained, with 3 lines being drawn perpendicular to the polishing marks to obtain mean values for each sample $(n=6)$. 2D and 3D images were captured at 2130x and 110x magnification, respectively.

\section{Surface Free Energy}

The contact angle was measured with a goniometer (SCA20, DataPhysics Instruments GmbH, Filderstadt, BW, Germany), by means of deionized water, ethylene glycol, and diiodomethane. Fresh thermally treated specimens were stored in sealed 24-well plates, and after $1 \mathrm{~h}$ at room temperature the three measurements were performed for each liquid. A cleaning protocol whereby ethanol was used to de-grease the sample surface was established prior to each drip. Pilot studies were performed by SEM to assess whether the cleaning protocol affected the BS covering, and no modifications were detected (data not shown). Each liquid was dropped onto dry surfaces, and contact angles were measured after $30 s(n=6)$. Surface free energy was indirectly measured from the contact angle values obtained for each liquid, by OWRK (Owens-Wendt-Rabel-Kaelble) method calculations with SCA20 software.

\section{Color Alteration}

The color alteration analysis was performed according to the $\mathrm{CIE} \mathrm{L}{ }^{*} \mathrm{a}{ }^{*} \mathrm{~b}{ }^{*}$ system (Commission Internationale de l'Eclairage), by means of a portable visible ultraviolet reflection spectrophotometer (Color Guide, BYK Gardner $\mathrm{GmbH}$, Gerestsried, Germany) at $400-$ to $700-\mathrm{nm}$ wavelength, standard illumination of D65, and lighting/ observation angle of $45 / 0^{\circ}$. Three readings were taken in each specimen for $\mathrm{Zr}$ and $\mathrm{Zr}+\mathrm{BS}$ groups, prior to and immediately after thermal treatment $(n=6)$. Total color alteration was calculated by the equation: $\Delta \mathrm{E}^{*}=\left[\left(\Delta \mathrm{L}^{*}\right)^{2}\right.$ $\left.+\left(\Delta \mathrm{a}^{*}\right)^{2}+\left(\Delta \mathrm{b}^{*}\right)^{2}\right] \mathrm{1} / 2$.

\section{Cell Seeding at Material Surfaces}

First, cytocompatibility of plain zirconia discs was evaluated in a pilot study $(n=6)$, and no statistically significant differences in $\mathbf{L 9 2 9}$ cell viability were found when they were seeded on zirconia or polystyrene surfaces for up to 7 days (data not shown). Therefore, the following experimental groups were established for biological assays: $\mathrm{Zr}$ - zirconia discs; and $\mathrm{Zr}+\mathrm{BS}$ - zirconia discs subjected to BS treatment $(n=6)$. The samples were adapted to a metallic device between two silicon rings to keep the discs in position and to standardize the seeding area. The sets were sterilized in ethylene oxide and placed individually in wells of 24-well plates. Then, L929 mouse fibroblast cells 
(subcutaneous connective tissue; ATCC ${ }^{\circledR}$ CCL $1^{\text {TM }}{ }^{\text {, Manassas, }}$ $\mathrm{VI}, \mathrm{USA}$ ) were seeded on material surfaces in Dulbecco's Modified Eagle's Medium (DMEM; supplemented with 100 $\mathrm{IU} / \mathrm{mL}$ penicillin, $100 \mu \mathrm{g} / \mathrm{mL}$ streptomycin, and $2 \mathrm{mmol} / \mathrm{L}$ glutamine; GIBCO, Grand Island, NY, USA), supplemented with $10 \%$ fetal bovine serum (FBS; GIBCO). One $30-\mu \mathrm{L}$ drop of culture medium containing $3 \times 104$ cells was applied exclusively to material surfaces, followed by a $30-\mathrm{min}$ incubation time at $37{ }^{\circ} \mathrm{C}$ and $5 \% \mathrm{CO} 2$, to allow for cell attachment in a $50 \%$ confluence pattern. Thereafter, 1 $\mathrm{mL}$ of culture medium was added to the sets, followed by further cultivation for up to 7 days.

\section{Cell Proliferation Assay}

After $1,3,5$, and 7 days of culture (DMEM plus 10\% FBS was changed every $72 \mathrm{~h}$ ), cell metabolic activity was assessed by the Alamar Blue ${ }^{\circledR}$ assay (Life Technologies; Grand Island, NY, USA), which indirectly describes cell proliferation over time. At each time-point, the culture medium was replaced by $1 \mathrm{~mL}$ of Alamar Blue ${ }^{\circledR}$ solution in DMEM with no FBS (1:10), followed by incubation for $3 \mathrm{~h}$ at $37{ }^{\circ} \mathrm{C}$ and $5 \% \mathrm{CO}_{2}$. Thereafter, a $100-\mu \mathrm{L}$ quantity of the supernatant was transferred to 96-well plates and analyzed on a fluorescence reader ( $540 \mathrm{~nm}$ excitation and 590 nm emission; Synergy H1, BioTek, Winooski, VT, USA).

\section{Cell Morphology}

After 1, 3, 5, and 7 days of culture (DMEM plus 10\% FBS was changed every $72 \mathrm{~h}$ ), the cells were fixed in 2.5\% glutaraldehyde buffer solution (VETEC Quimica Fina LTDA, Duque de Caxias, RJ, Brazil) for $24 \mathrm{~h}$, followed by post-fixation with $1 \%$ osmium tetroxide (SigmaAldrich, St. Louis, MO, USA) at room temperature. Then, the samples were dehydrated in ethanol (30\%, $50 \%, 70 \%, 95 \%$, and 100\%), chemically dried in HMDS $(1,1,1,3,3,3$-hexamethyldisilazane; Sigma-Aldrich), and desiccated for $72 \mathrm{~h}$. The samples were mounted on metallic stubs, stored in a vacuum desiccator for 7 days at room temperature, and sputter-coated with a gold layer (Denton Vacuum; Desk V - Moorestown, NJ, USA). Cell morphology was then examined under a scanning electronic microscope (JMS-6610V Scanning Microscope, Tokyo, Japan).

\section{Collagen Synthesis}

After cells were seeded, the sets were incubated in $1 \mathrm{~mL}$ DMEM with no FBS, and the culture medium was collected after each $72 \mathrm{~h}$, up to 7 days. The extracts for every sample were stored at $-20{ }^{\circ} \mathrm{C}$. A $500-\mu \mathrm{L}$ aliquot of pooled extracts was transferred to tubes containing the same volume of Direct Red (Sigma-Aldrich, Saint Louis, MO, USA) solution saturated in picric acid $(0.1 \%)$. The specimens were then incubated for $1 \mathrm{~h}$ while being stirred at 400 rpm in a dry bath at $25^{\circ} \mathrm{C}$. The tubes were centrifuged at $12,000 \mathrm{rpm}$ for $10 \mathrm{~min}$, the supernatant was discarded, and then $300 \mu \mathrm{L}$ of $0.01 \mathrm{M}$ hydrochloric acid were added. The tubes were centrifuged again $(12,000 \mathrm{rpm} / 10 \mathrm{~min})$, the supernatant was discarded, and a $250-\mu \mathrm{L}$ quantity of $0.5 \mathrm{M}$ sodium hydroxide was added to solubilize the precipitated material. An aliquot of $100 \mu \mathrm{L}$ of each sample was evaluated by spectrophotometry (Synergy H1, BioTek) at 555-nm wavelength.

\section{Cell Migration Assay}

This analysis was performed by a wound-healing assay $(n=4)$. Cells were seeded at a $100 \%$ confluence pattern at material surfaces ( $6 \times 104$ cells/material). After a $24-h$ incubation, an in vitro wound was created in the center of each disc, by use of a 1-mL pipette tip to scratch the monolayer formed by the attached cells. Then, the sets were incubated with DMEM with no FBS for $24 \mathrm{~h}$. The cells were immersed in 70\% ethanol and stained with crystal violet (Synth, Diadema, SP, Brazil) for measurement of the wound area, as previously described in detail by Basso et al. (9).

\section{Data Analysis}

To verify the reproducibility of the data, two independent experiments were performed. Data were compiled and evaluated by the Shapiro-Wilk normality test. Surface roughness, color parameters, contact angle, and free surface energy were analyzed by Student's t-test. Repeated-measures two-way ANOVA was performed for the cell proliferation assay. Student's t-test was used to find the differences between groups at each time-point, and Tukey's test was used to find the differences among time-points, for each group. Data from collagen synthesis and wound healing were evaluated by Student's t-test. All statistical comparisons were performed at the $5 \%$ significance level.

\section{Results}

\section{Surface Characterization}

The surface topography of the $\mathrm{Zr}$ group was characterized by a homogeneous crystalline microstructure (Fig. $1 \mathrm{~A}$ and $1 \mathrm{~B}$ ), composed of oxygen (0) and zirconia (Zr) (Fig. 1C). Thermal treatment with BS suspension caused deposition of an amorphous layer onto the zirconia surface (Fig. 1D and 1E). The EDX analysis performed on this layer demonstrated the presence of oxygen (0), sodium ( $\mathrm{Na}$ ), silica (Si), and phosphorus (P) (Fig. 1F). Deposition of BS particles onto the zirconia surface was also detected by confocal microscopy. The Zr group featured a homogeneous flat surface (Fig. 2A and 2B), whereas the $\mathrm{Zr}+\mathrm{BS}$ group showed the presence of irregular particles, creating several peak areas (Fig. 2C and 2D). A significant increase $(p<0.05)$ in $R a$ values was observed in the $\mathrm{Zr}+\mathrm{BS}$ group 
(64.79 $\mu \mathrm{m})$ compared with the $\mathrm{Zr}$ group $(0.26 \mu \mathrm{m})$ (Fig. $2 \mathrm{E})$. The $\mathrm{Zr}+\mathrm{BS}$ group also featured reduced contact angles for diiodomethane and water, as well as increased surface free energy $(p<0.05)$, in comparison with the Zr group (Fig. 3). No significant alteration ( $p>0.05)$ in color parameters was detected between groups (Table 1). Mean $\Delta \mathrm{E}$ for the
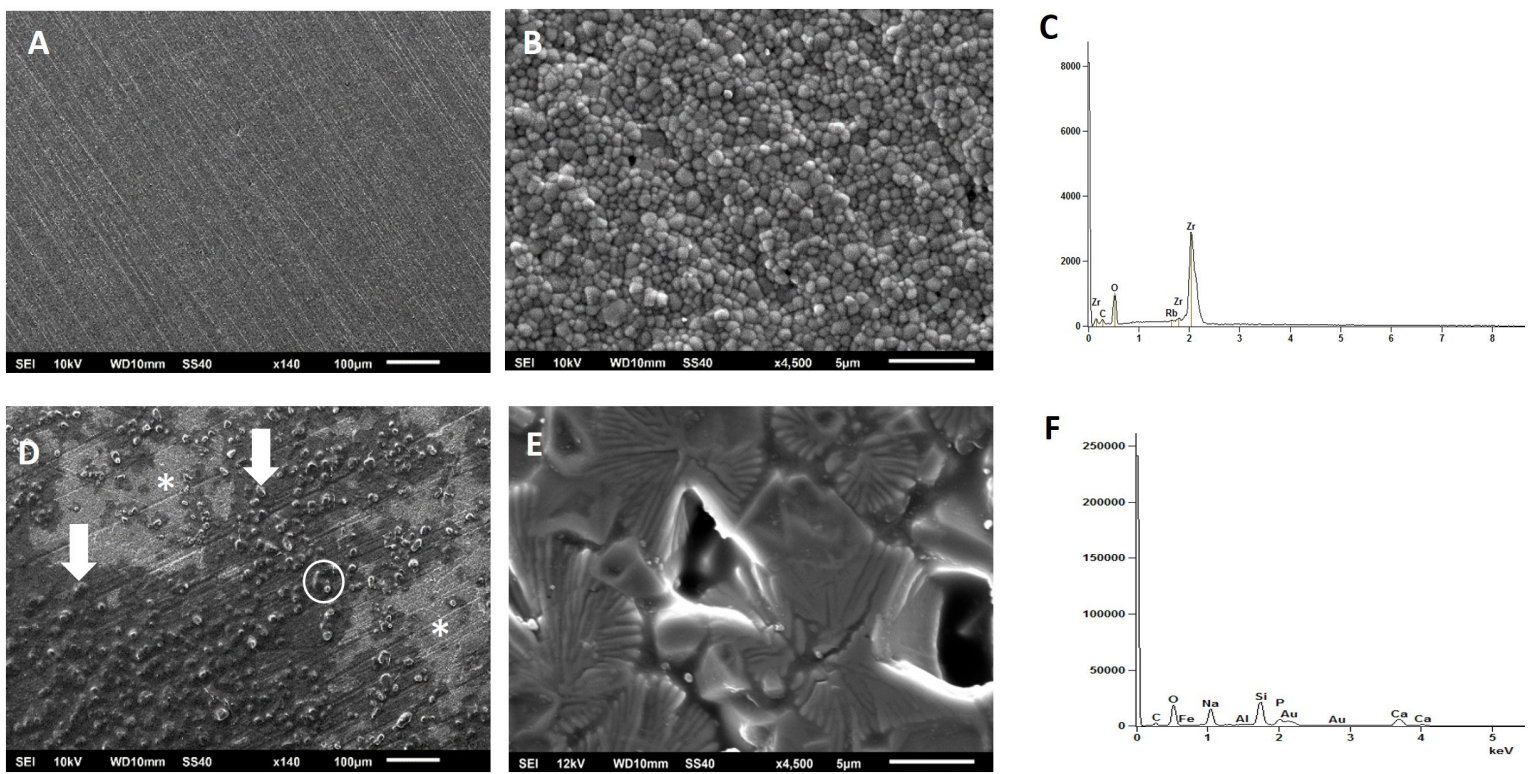

Figure 1. Topography and chemical composition of sample surfaces. A: Low-magnification image (140x) of Zr group surfaces. B: High-magnification image (4500x) of Zr surface. Note the homogeneous crystalline microstructure. C: EDX analysis of the $\mathrm{Zr}$ group demonstrating the presence of zirconia ( $\mathrm{Zr}$ ) and oxygen (0). D: Low-magnification image (140x) of $\mathrm{Zr}+\mathrm{BS}$ group surfaces. Arrows indicate the amorphous layer deposited on s the zirconia surface. Asterisk indicates plain zirconia surface. E: High-magnification image (4500x) of $\mathrm{Zr}+\mathrm{BS}$ surfaces, indicated in circled area in D. Note the crystal-like morphology of particles deposited on the Zr surfaces after thermal treatment with BS. F: EDX analysis of the Zr+BS group representative of circled area in $\mathrm{D}$, demonstrating the presence of oxygen $(0)$, sodium $(\mathrm{Na})$, silica $(\mathrm{Si})$, and phosphorus $(\mathrm{P})$.
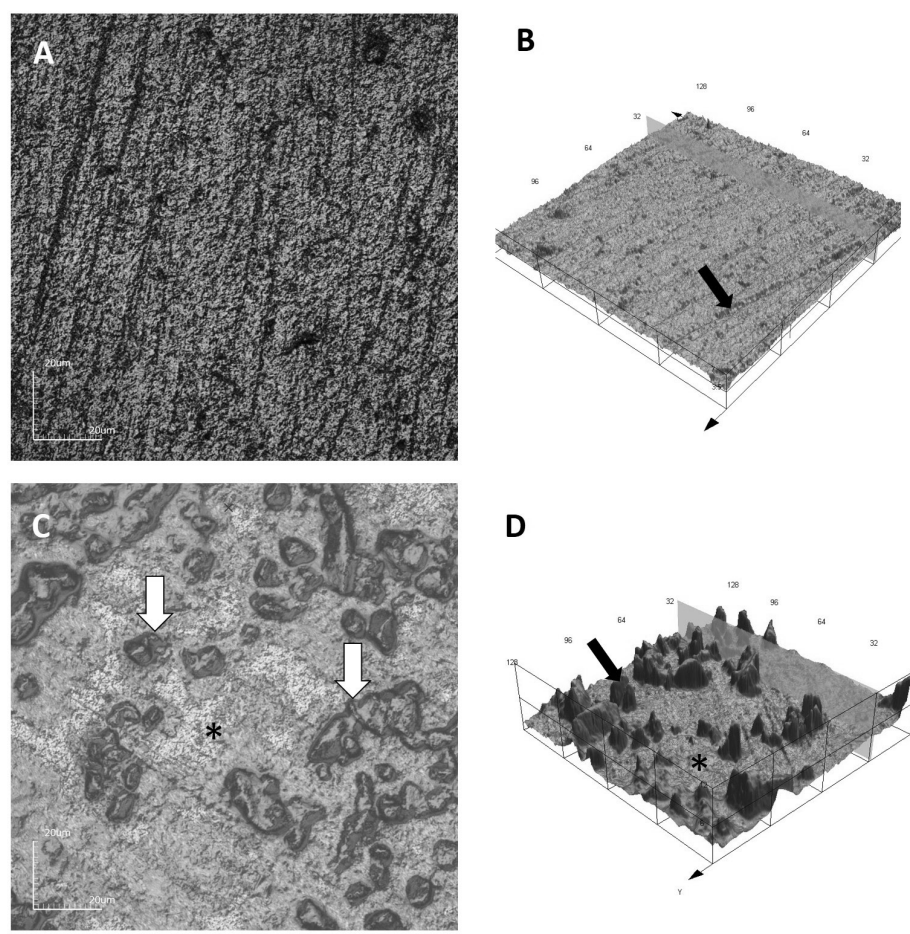

D

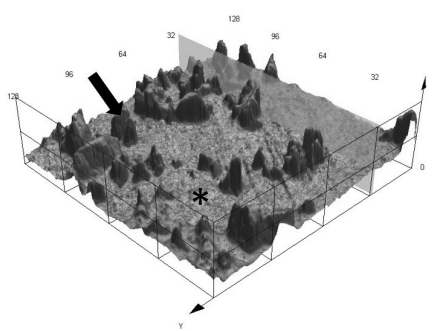

E

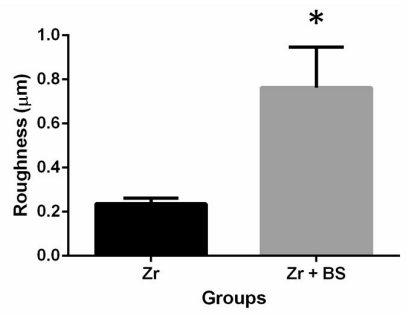

Figure 2. Confocal analysis of disc surfaces. A and B: 2D and 3D images, respectively, of Zr group surfaces. Note the flat surface and the presence of polishing lines (black arrow in B). C and D: 2D and 3D images, respectively, of the $\mathrm{Zr}+\mathrm{BS}$ group. Arrows indicate the particles deposited on the discs after thermal treatment with BS, creating large peak areas (black arrow in D). Asterisk indicates plain zirconia surface. E: Bar graph representative of mean (standard deviation) of Ra values for each group. Asterisk indicates significant difference from the Zr group (Student's t-test; $p<0.05$ ). 
$\mathrm{Zr}$ and $\mathrm{Zr}+\mathrm{BS}$ groups was below 3.7, which is considered clinically imperceptible (10).

\section{Biologic Assays}

Cells seeded on both tested surfaces were capable of proliferating significantly over time up to 5 days $(p<0.05)$. Increased cell viability values $(p<0.05)$, of around $62.5 \%$, $69.6 \%$, and $52.8 \%$, were found for the $\mathrm{Zr}+\mathrm{BS}$ group at 3,5 , and 7 days, respectively, in comparison with the $\mathrm{Zr}$ group (Fig. 4A). The SEM analysis revealed that cells were able to adhere to both surfaces from day 1 ; nevertheless, cells in the $\mathrm{Zr}+\mathrm{BS}$ group were capable of spreading faster throughout the material surface in comparison with those in the Zr group, since the cells covered the entire disc surface from day 3 in this group, whereas this phenomenon was detected from day 5 in the Zr group (Fig. $4 B$ and 4 C). An increase of around $57 \%$ in collagen synthesis $(p<0.05)$ and a reduction of around $54.6 \%$ in wound area $(p<0.05)$ were

Table 1. Mean values for color alteration parameters according to CIE L*a*b*

\begin{tabular}{lcccc}
\hline \multirow{2}{*}{ Group } & \multicolumn{4}{c}{ Color parameters } \\
\cline { 2 - 5 } & $\Delta \mathrm{E}$ & $\Delta \mathrm{L}$ & $\Delta \mathrm{b}$ & $\Delta \mathrm{a}$ \\
$\mathrm{Zr}$ & $1.62(1.05)$ & $-0.12(1.50)$ & $0.02(0.80)$ & $-0.06(0.90)$ \\
$\mathrm{Zr}+\mathrm{BS}$ & $1.92(0.76)$ & $-0.82(1.82)$ & $0.29(0.48)$ & $-0.01(0.36)$ \\
\hline
\end{tabular}

*No significant differences were found between groups for each color parameter (Student's t-test; $p>0.05$ ). detected for the $\mathrm{Zr}+\mathrm{BS}$ group compared with the $\mathrm{Zr}$ group (Fig. 4D and 4E). Representative images of the wound area in both groups are shown in Figure 4.

\section{Discussion}

Zirconia appears to be an adequate material for abutment since it shows esthetic and biocompatibility features superior to those of titanium (1). Currently, researchers have focused on the establishment of bioactive interfaces between zirconia and peri-implant soft tissues, since the tissue barrier around abutments protects the underlying bone against resorption and maintains gingival shape (11). GFs play a key role in the development and maintenance of the soft-tissue barrier. These cells are present in the narrow zone of connective tissue adjacent to abutments. The topography and physicochemistry of abutment surfaces directly affect the responses of GFs to material interfaces (11). During the healing process following implant surgery, marginal gingiva is often wounded, with the first step of soft-tissue regeneration being mainly dictated by the migration, attachment, and proliferation of GFs to the wounded area to produce the underlying collagen matrix (1). Therefore, in this study, we proposed the development of a bioactive glass coating on zirconia surfaces, by means of thermal treatment with Biosilicate ${ }^{\circledR}$ (BS) particles. The effect of a Zr-BS-covered surface on $L 929$ mouse fibroblast migration, adhesion, proliferation, and collagen expression was evaluated. According to the results, the null hypothesis was rejected, since the BS coating indeed affected the function of L929 cells.

Surface morphology and
A
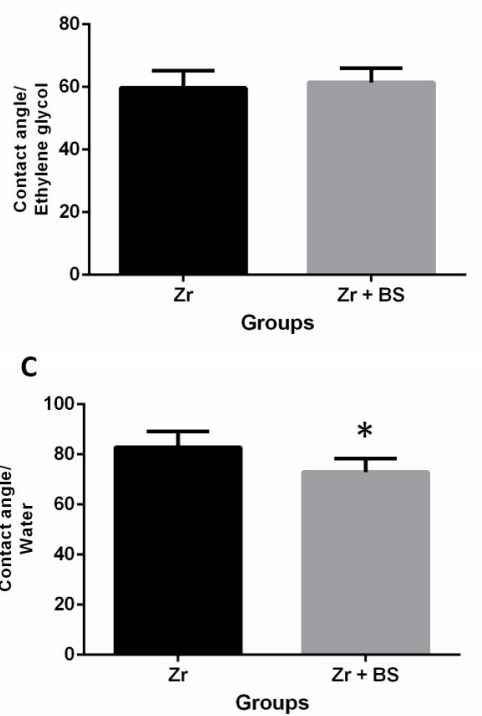

B

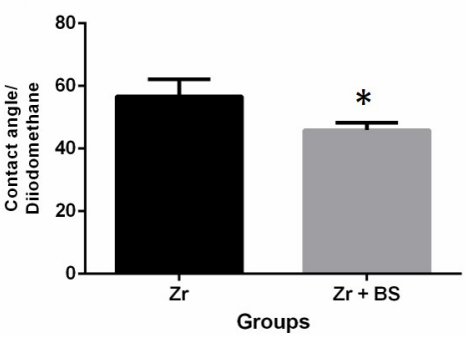

D

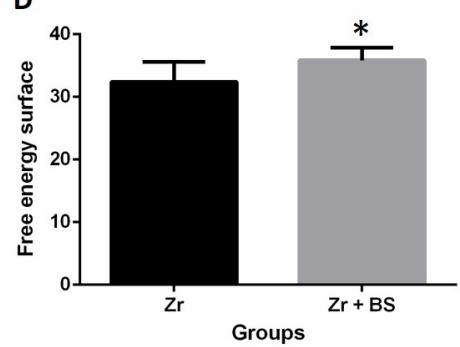

Figure 3. Bar graph of mean (standard deviation) contact angle values for ethylene glycol (A), diiodomethane (B), water (C), and free energy surface (D). Asterisks demonstrate significant differences from the Zr group (Student's t-test; $\mathrm{p}<0.05$ ). topography following BS treatment were first examined. SEM/EDX analysis demonstrated the presence of the BS layer partially covering the zirconia surface, significantly affecting its physical characteristics. BS-treated zirconia featured an Ra medium value of $64.79 \mu \mathrm{m}$, which represents an increase of around 249 times the surface roughness of zirconia after thermal treatment with BS. The optimal surface roughness of implant abutments to promote a sustained soft-tissue seal has yet to be determined, since studies on the behavior of fibroblasts on modified abutment surfaces have yielded controversial results. In vivo studies demonstrated that nanotopography decreased the 
adhesion and spreading of fibroblasts, with cells featuring greater affinity for micro-grooved surfaces $(3,12)$. Others have demonstrated that rougher ceramic surfaces increased protein and cell adsorption (13).

In contrast, authors have established a threshold from 0.20 to $0.34 \mu \mathrm{m}$ Ra as the ideal roughness for GF

A

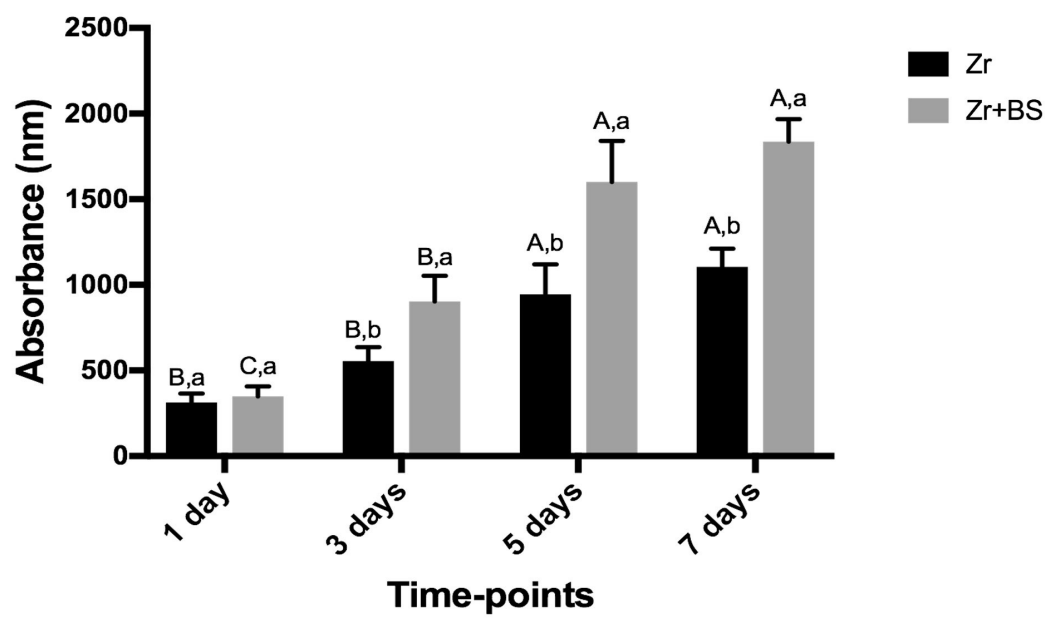

B

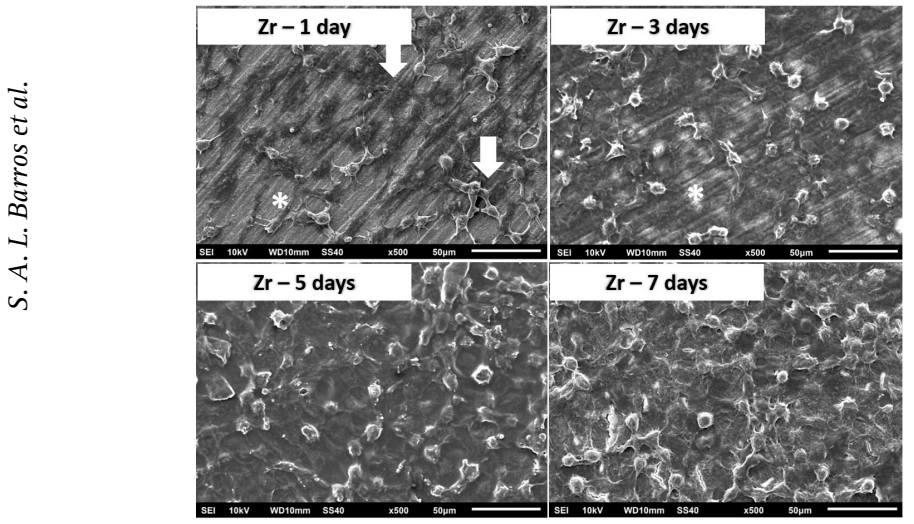

C

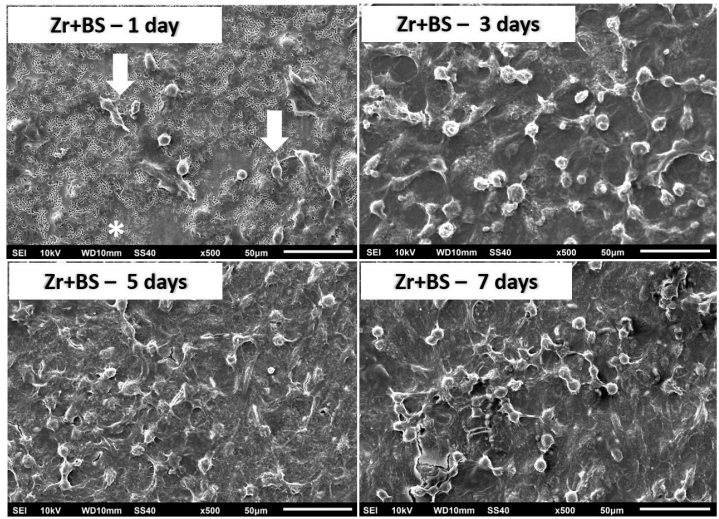

D

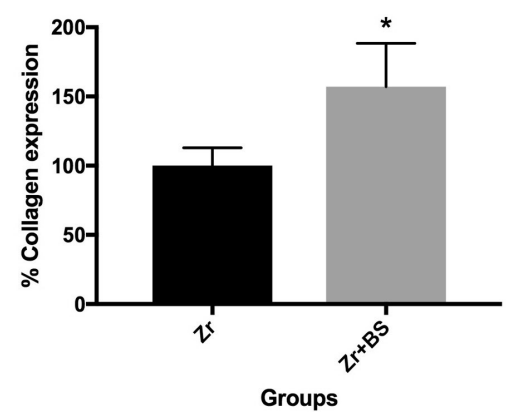

E

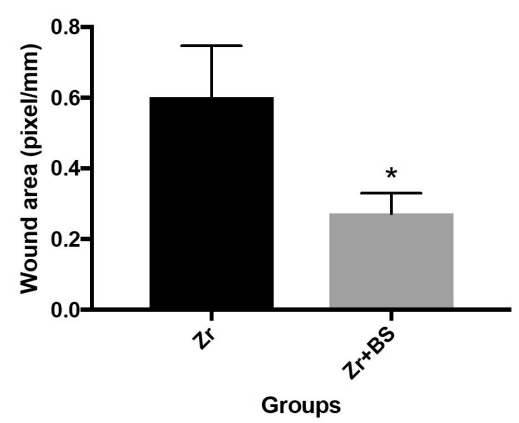

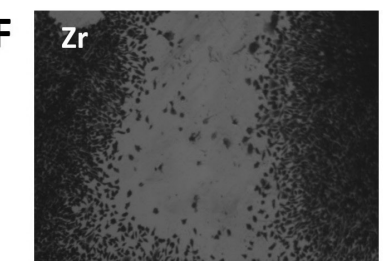

$\mathrm{Zr}+\mathrm{BS}$

Figure 4. A: Bar graph representative of mean (standard deviation) values of cell proliferation by Alamar Blue ${ }^{\circledR}$ assay. Lower-case letters allow for comparison between groups at each time-point (Student's t-test); Upper-case letters allow for comparison among time-points, for each group (Tukey's test). Different letters indicate significant differences ( $<<0.05)$. B and C: Panel of SEM images (500x) for Zr and Zr+BS groups, respectively, at each time-point. Note that cells (arrows) partially covered the surfaces of samples at day 1 in both groups; however, the cells in the Zr+BS group were capable of covering the entire material surface from day 3. This phenomenon was observed from day 5 in the $\mathrm{Zr}$ group. D and E: Bar graph representative of mean (standard deviation) values of collagen expression and wound area, respectively. Asterisk indicates significant difference from the Zr group (Student's t-test; $\mathrm{p}<0.05$ ). F: Representative images of the wound area in both groups. 
adhesion and proliferation (14). It was previously observed that smooth surfaces (Ra below $0.2 \mu \mathrm{m}$ ) favor the initial adhesion of GFs to zirconia; however, this feature has no significant effect on late cell proliferation and phenotype expression (11). Conversely, Esfahanizadeh et al. (4) detected significantly higher fibroblast adhesion and proliferation on $1.3 \mu \mathrm{m}$ rough titanium surfaces in comparison with 0.2-0.4 $\mu \mathrm{m}$ surfaces. In our study, instead of the highly rough surface produced after BS treatment, it was possible to observe, on SEM analysis, that L929 cells were capable of attaching similarly in the $\mathrm{Zr}$ and $\mathrm{Zr}+\mathrm{BS}$ groups at day 1 , with cells in the $Z r+B S$ group spreading in larger areas after 3 days of cell culture. Indeed, cells on BS-covered zirconia featured increased proliferation capability over time, as demonstrated by Alamar Blue ${ }^{\circledR}$ assay. It is important to notice that roughness is an important factor for biofilm development on abutment surfaces. Researchers have observed that Ra values above $0.2 \mu \mathrm{m}$ were associated with early biofilm formation (2). Although the highly rough surface was generated by BS treatment, it has already been demonstrated that Biosilicate ${ }^{\circledR}$ features a broad spectrum of antimicrobial properties, including anaerobic microorganisms (15). However, more studies are necessary to evaluate the biofilm formation on zirconia surfaces covered with BS.

In the present study, instead of thermal treatment with BS leading to significant increases in zirconia Ra values, the contact angles for water and diiodomethane were reduced in the presence of BS, leading to increased free energy surfaces. According to Yang et al. (11), treatments that lead to increased surface hydrophilicity play a positive role in human GF proliferation and collagen expression when they are performed on rougher zirconia surfaces than on smooth ones. Therefore, it seems that a hydrophilic rough zirconia surface has a bioactive effect on GFs. Similarly, the in vivo study conducted by Garcia et al. (5) demonstrated that titanium abutments with increased wettability resulted in higher connective cell adhesion and collagen fiber density deposition to material surfaces in comparison with nontreated samples. In our study, we also detected increased proliferation and collagen expression on $\mathrm{L929}$ cells seeded onto BS-covered zirconia discs in comparison with plain zirconia, demonstrating that the combination of a rough surface with increased wettability favored fibroblast maturation, leading to increased collagen deposition.

Regardless of the physical modifications of zirconia surfaces mediated by thermal treatment with BS, the bioactive potential of this novel coating may be attributed to bioactive glass (BG) composition itself. BS particles used in the present investigation are composed of a crystallized glass-ceramic from the quaternary $23.75 \% \mathrm{Na}_{2} \mathrm{O}, 23.75 \%$ $\mathrm{CaO}, 48.5 \% \mathrm{SiO}_{2}, 24 \% \mathrm{P}_{2} \mathrm{O}_{5}$ system (16). This biomaterial has composition similar to that of Bioglass $® 45 \mathrm{~S} 5$, the gold standard BG; however, BS features enhanced mechanical properties (16). These BGs have been widely studied as suitable biomaterials for orthopedic applications and bone tissue engineering, due to their ability to influence the behavior of osteoblast cells, by creating a hydroxyapatite layer after contact with organic fluids, effectively bonding the material to surrounding host tissues $(6,17)$. According to Crovace et al. (7), BS has the highest bioactivity index (IB>8) among all commercial BGs. Studies have demonstrated the superior potential of $\mathrm{BS}$ for osteogenesis in comparison with Bioglass ${ }^{\circledR} 45 \mathrm{~S} 5(6,7)$. Both materials release $\mathrm{Ca}$, $\mathrm{Si}$, $\mathrm{Na}$, and $\mathrm{P}$ ions upon contact with fluids, with bioactivity on bone cells being related to creation of an alkaline microenvironment, which modulates osteoblast and/or precursor cell functions (6).

Nevertheless, it has been shown that BGs with high levels of bioactivity can also bond to soft connective tissues, accelerating wound healing (17). According to Hench (17), a primary requirement for the successful application of BGs for soft-tissue regeneration is a rapid formation of an interfacial collagen bond, preventing micro-motion at the material/host tissue interface. Following subcutaneous implantation, researchers have found healthy tissue growth and adhesion around Bioglass ${ }^{\circledR} 45 \mathrm{~S} 5$ implants, with no inflammatory reaction and mild foreign body reaction, while the scaffolds were fully invaded by well-vascularized connective tissue (18). The creation of collagen bonding on surfaces coated with Bioglass ${ }^{\circledR} 45 \mathrm{~S} 5$ has already been demonstrated in literature for silicone medical devices, improving tissue retention since they promoted adhesion by collagen and increased cell proliferation (19). It has also been shown that BS has the ability to form strong collagen-mediated bonds to soft tissues (8). Following implantation of BS samples on connective tissues, a collagen-rich matrix and cell ingrowth can be observed, securing neo-tissue genesis (8). Kido et al. (8) observed that the components released from BS scaffolds increased L929 cell proliferation, mainly at concentrations of $12.5 \%$, after 3 and 5 days of cell culture in vitro; nevertheless, $100 \%$ concentrated extracts diminished the proliferative capability of L929 cells. Based on this result, we selected a concentration of BS suspension capable of covering 100\% of the zirconia surface. From this parameter, we chose a 90\% less concentrated BS suspension to be applied to $\mathrm{Zr}$ discs, which led to partial surface covering. According to the results, this surface successfully induced L929 migration, proliferation, and collagen expression compared with plain Zr surfaces.

According to Hench (17), BG bioactivity with soft tissues is mainly governed by the time-dependent dissolution and precipitation reactions that occur at the implant interface 
upon contact with physiological fluids, in the same way as has been described for bone regeneration. Therefore, the increase in $\mathrm{Ca}, \mathrm{Si}, \mathrm{Na}$, and $\mathrm{P}$ ion concentrations results in a local $\mathrm{pH}$ increase and deposition of a carbonated hydroxyapatite layer. This crystalline layer provides the bonding interface between the material surface and surrounding soft tissue (17). Previously reports have demonstrated that BGs can modulate all the phases involved on wound healing, by modulating fibroblasts behavior and gene/protein expression pattern (18-22). In the early phase of wound healing (2-3 days), fibroblasts migrate and proliferate on wound site, and express growth factors capable to modulate angiogenesis, epithelialization and extracellular matrix (ECM) deposition, such as basic fibroblastic growth factor (bFGF), epidermal growth factor (EGF) and vascular endothelial growth factor (VEGF). These cells also produce the ECM proteins to support cell growth and granulation tissue bed for vascularization, such as collagen and fibronectin. In a late phase, fibroblasts differentiate into myofibroblasts, to accelerate wound contraction (23).

Day et al. (22) seeded a fibroblastic cell lineage (CCD$18 \mathrm{Co}$ ) onto Bioglass ${ }^{\circledR} 45 \mathrm{~S} 5$-coated acrylic plates and observed increased gene expression of bFGF. The authors correlated this result with ion dissolution from BG and increased $\mathrm{pH}$ of the culture medium. Others reported that $\mathrm{I}$, as well as mitosis-related genes (CDKN1A and Cyclin A) by fibroblasts in vitro $(24,25)$. Yu et al. $(20)$ demonstrated that dermal human fibroblasts cultured in contact with a BG ionic dissolution products ( $\mathrm{Ca}, \mathrm{P}$ and $\mathrm{Si}$ ) maintained cell viability, and increased cell migration (wound healing assay) and ECM proteins secretion (collagen I and fibronectin), similarly as observed in the present investigation. These effects were correlated with increased gene expression of bFGF, EGF and VEGF; while control cells had a peak at 3 days with decrease at 7 days, BG-treated groups sustained the gene expression of these growth factors from 3 to 7 days in vitro. After being cultivated for 3 days in contact with $B G$, the cells also had increase on collagen I and fibronectin expressions. Additionally, when BG-treated fibroblasts were implanted with a skin graft into wounds created on nude mice, the authors observed increased wound healing capability, which was mediated by both, transplanted and host cells.

In our experiment we detected increased migration to the wound area in vitro for $\mathbf{L 9 2 9}$ cells seeded onto BScoated surface, along with increase on cell proliferation and collagen deposition. These cell events are related with the creation of granulation tissue at early stages of wound healing. Acceleration on fibroblast migration into wound area, increase on new blood vessels formation, ECM deposition and re-epithelization, has been proven to fasten wound healing $(19,20)$.

Yu et al. (20) also demonstrated that BG ion dissolution was capable to stimulate myofibroblast differentiation by $\alpha$-SMA (alpha-smooth muscle actin) expression in vitro, and following in vivo implantation. This effect was correlated with improved wound healing capability. Increase on L929 fibroblast proliferation in the presence of PLGA/ BS biomaterials in vitro, along with fastened soft tissue infiltration and tissue regeneration in rats was recently demonstrated by Fernandez et al. (21), proving the potential of this bioglass to fasten soft tissue regeneration. In the present investigation, EDX analysis detected the presence of $\mathrm{Na}, \mathrm{Si}, \mathrm{P}$, and $\mathrm{Ca}$ in the $\mathrm{Zr}+\mathrm{BS}$ group; therefore, one can speculate that the improved L929 behavior at this surface may be related to the release of BS ions from the zirconia surface, promoting a favorable environment for cell viability and collagen expression, such as demonstrated in previous investigations (8).

In addition to promising biological effects, the BScovered surface did not affect CIE L ${ }^{*} \mathrm{a}^{*} \mathrm{~b}^{*}$ color parameters of zirconia surfaces. Therefore, regardless of the limitations of this in vitro study, the deposition of a BS layer on zirconia surfaces by thermal treatment offers a significant potential for applications in soft tissue regeneration following dental implant surgery, since this covering features a bioactive potential on a fibroblast lineage from connective tissue, resulting in increased cell proliferation, spread, migration, and collagen expression, with no alterations of the esthetic characteristics of zirconia. One can speculate that the development of new dental materials based on this technology may fasten wound healing of soft tissue surrounding implant components, minimizing bacterial penetration and providing a more stable seal at abutment/ transmucosal implants surface. Therefore, in vivo studies should be carried out within this research field to evaluate the real benefits of covering implant components with bioglass.

However, the influence of the physical and chemical characteristics of this novel substrate on cell responses has not been completely elucidated. Also, investigating the effect of this new surface on fibroblasts from human gingival tissue would provide a better scientific evidence of the benefits of covering dental implants components with Biosilicate ${ }^{\circledR}$, since in the present and previously investigations with this specific bioglass was solely evaluated on fibroblasts from mouse connective tissue (L929 cells) and by in vivo models with rats. Since the regenerative potential of murine/rat cells are increased in comparison with human tissues, the results observed in the present investigation may be overestimated $(19,21)$. Thus, 
more studies are needed to further our understanding of the mechanisms surrounding these effects, as well as the long-term stability, collagen bond strength, and adhesion of microorganisms in the oral flora.

\section{Resumo}

0 objetivo deste estudo foi o desenvolvimento de um recobrimento de vidro bioativo sobre a zircônia (Zr) para modular o fenótipo de fibroblastos gengivais. Para este propósito, partículas de Biosilicato® $(6 \mathrm{mg} / \mathrm{mL})$ em um veículo a base de água/álcool isopropílico (1:1) foram aplicadas sobre discos de zircônia seguido por tratamento térmico a $1100{ }^{\circ} \mathrm{C}$ por $20 \mathrm{~min}$. A topografia de superficie (MEV), composição quimica (EDX), rugosidade de supefície (Ra; microscopia confocal), energia livre de superficie (goniômetro) e alteração de cor (Espectrofotometria UV-vis) foram avaliadas $(n=6)$. A seguir, fibroblastos $L 929$ foram semeados sobre discos de Zr e BS+Zr e a proliferação (Alamar Blue; $n=6)$, morfologia (MEV; $n=2)$, migração celular (wound healing; $n=4$ ) e a síntese de colágeno (Sirius Red; $\mathrm{n}=6$ ) foram avaliados até 7 dias. Os dados foram analisados pelos testes ANOVA/Tukey $(\alpha=5 \%)$. Um recobrimento homogêneo consistindo de Si, $\mathrm{Na}, \mathrm{O}$ e Ca foi detectado na superfície da $\mathrm{Zr}$ após o tratamento térmico com BS, o qual promoveu um aumento significante na rugosidade e energia livre de superficie $(p<0,05)$. Nenhuma mudança nos parâmetros de cor foi observada $(p>0,05)$. Células semeadas na superfície de $Z r+B S$ apresentaram maior proliferação, expressão de colágeno e capacidade de migração em comparação com aquelas cultivadas sobre a superficie de $\mathrm{Zr}(\mathrm{p}<0,05)$. Imagens de MEV revelaram que o espalhamento celular ocorreu mais rápido na presença de BS. Assim, conclui-se que o tratamento térmico da superficie da Zr com BS levou a deposição de um recobrimento bioativo, o qual induziu in vitro o espalhamento, proliferação e migração de fibroblastos gengivais e expressão de colágeno.

\section{Acknowledgements}

The authors acknowledge the Fundação de Amparo à Pesquisa do Estado de São Paulo (FAPESP - grants \#2016/15674-5 and 2015/19034-8).

\section{References}

1. Pabst AM, Walter C, Bell A, Weyhrauch M, Schmidtmann, Scheller H. Influence of CAD/CAM zirconia for implant-abutment manufacturing on gingival fibroblasts and oral keratinocytes. Clin Oral Invest 2016;20:1101-1108.

2. Grobner-Schreiber $B$, Herzog $M$, Hedderich J, Dück $A$, Hannig $M$, Griepentrog M. Focal adhesion contact formation by fibroblasts cultured on surface-modified dental implants: An in vitro study. Clin Oral Implants Res 2006;17:736-745.

3. Nevins M, Nevins ML, Camelo M, Boyesen JL, Kim DM. Human histologic evidence of a connective tissue attachment to a dental implant. Int J Periodontics Rest Dent 2008;28:111-121.

4. Esfahanizadeh N, Motalebi S, Daneshparvar N, Akhoundi N, Bonakdar S. Morphology, proliferation, and gene expression of gingival fibroblasts on Laser-Lok, titanium, and zirconia surfaces. Lasers Med Sci 2016;31:863-873.

5. Garcia B, Camacho F, Peñarrocha D, Tallarico M, Perez S, Canullo L. Influence of plasma cleaning procedure on the interaction between soft tissue and abutments: A randomized controlled histologic study. Clin Oral Implants Res 2017;28:1269-1277.

6. Montazerian M, Zanotto ED. History and trends of bioactive glassceramics. J Biomed Mater Res Part A 2016;104:1231-1249.

7. Crovace MC, Souza MT, Chinaglia CR, Peitl 0 , Zanotto ED. Biosilicate - A multipurpose, highly bioactive glass-ceramic. in vitro, in vivo and clinical trials. J Non Cryst Solids 2016;432:90-110.
8. Kido HW, Oliveira P, Parizotto NA, Crovace MC, Zanotto ED, Peitl-Filho 0 , et al. Histopathological, cytotoxicity and genotoxicity evaluation of Biosilicate glass-ceramic scaffolds. J Biomed Mater Res - Part A 2013;101:667-673.

9. Basso F, Pansani T, Turrioni A, Bagnato V, Hebling J, de Souza Costa C. In vitro wound healing improvement by low-level laser therapy application in cultured gingival fibroblasts. Int J Dentistry 2012;2012:1-6.

10. Browning $W$, Contreras-Bulnes $R$, Brackett $M$, Brackett W. Color differences: Polymerized composite and corresponding Vitapan Classical shade tab. J Dentistry 2009;37:34-39.

11. Yang $Y$, Zhou J, Liu X, Zheng M, Yang J, Tan J. Ultraviolet light-treated zirconia with different roughness affects function of human gingival fibroblasts in vitro: The potential surface modification developed from implant to abutment. J Biomed Mater Res - Part B Appl Biomater 2015;103:116-124.

12. Thoma $D$, Jones $A$, Dard $M$, Grize $L$, Obrecht $M$, Cochran D. Tissue integration of a new titanium-zirconium dental implant: a comparative histologic and radiographic study in the canine. J Periodontol 2011;82:1-11.

13. Yamashita $D$, Machigashira $M$, Miyamoto $M$, Takeuchl $H$, Noguchi $K$, Izumi $Y$ et al. Effect of surface roughness on initial responses of osteoblast-like cells on two types of zirconia. Dent Mater J 2009;28:461-470.

14. Brunot-Gohin C, Duval J, Azogui E, Jannetta R, Pezron I, LaurentMaquin $D$ et al. Soft tissue adhesion of polished versus glazed lithium disilicate ceramic for dental applications. Dent Mater 2013;29:205212.

15. Martins C, Carvalho T, Souza M, Ravagnani C, Peitl O, Zanotto E et al. Assessment of antimicrobial effect of Biosilicate ${ }^{\circledR}$ against anaerobic microaerophilic and facultative anaerobic microorganisms. J Mater Sci: Mater Med 2011;22:1439-1446.

16. Zanotto ED, Ravagnani C, Peitl O, Panzeri H, Lara EH. Process and compositions for preparing particulate, bioactive or resorbable biosilicates for use in the treatment of oral ailments. US Patent Application No. 10/540,365.2006 Nov 9.

17. Hench L. The future of bioactive ceramics. J Mater Sci: Mater Med 2015;26:1-4.

18. Ross E, Batich C, Clapp W, Sallustio J, Lee N. Tissue adhesion to bioactive glass-coated silicone tubing in a rat model of peritoneal dialysis catheters and catheter tunnels. Kidney Int. 2003;63:702-708.

19. Miguez-Pacheco V, Hench LL, Boccaccini AR. Bioactive glasses beyond bone and teeth: emerging applications in contact with soft tissues. Acta Biomater 2015;13:1-15

20. Yu H, Peng J, Xu Y, Chang J, Li H. Bioglass Activated Skin Tissue Engineering Constructs for Wound Healing. ACS Appl Mater Interfaces 2016;13;8:703-715.

21. Fernandes KR, Magri AMP, Kido HW, Ueno F, Assis L, Fernandes KPS, et al. Characterization and biological evaluation of the introduction of PLGA into biosilicate ${ }^{\circledR}$. J Biomed Mater Res B Appl Biomater 2017;105:1063-1074

22. Day R. Bioactive glass stimulates the secretion of angiogenic growth factors and angiogenesisin vitro. Tissue Eng 2005;11:768-777.

23. Darby $I A$, Laverdet $B$, Bonté $F$, Desmoulière $A$. Fibroblasts and myofibroblasts in wound healing Clin Cosmet Investig Dermatol 2014;7:301-311

24. Hench LL, Xynos ID, Chang J. Gene activating glasses. J Inorg Mater 2002;17:897-909.

25. Xynos I, Edgar A, Buttery L, Hench L, Polak J. Gene-expression profiling of human osteoblasts following treatment with the ionic products of Bioglass $^{\circledR}$ 45S5 dissolution. J Biomed Mater Res 2001;55:151-157.

Received December 17, 2018 Accepted February 19, 2019 